EDYTA PACZOS-GRZEDA ${ }^{1}$

SYLWIA SOWA ${ }^{1}$

ANETA KOROLUK ${ }^{1}$

JOANNA TOPOROWSKA ${ }^{1}$

EWELINA MAREK ${ }^{1}$

PIOTR BEDNAREK ${ }^{2}$

${ }^{1}$ Instytut Genetyki, Hodowli i Biotechnologii Roślin, Uniwersytet Przyrodniczy w Lublinie

${ }^{2}$ Instytut Hodowli i Aklimatyzacji Roślin - Państwowy Instytut Badawczy, Radzików

Kierownik Tematu: dr Edyta Paczos-Grzẹda Uniwersytet Przyrodniczy w Lublinie Instytut Genetyki,

Hodowli i Biotechnologii Roślin ul. Akademicka 15, 20-934 Lublin, (81) 4456884,

e-mail: edyta.paczos@up.lublin.pl

Prace zostały wykonane $w$ ramach badań podstawowych na rzecz postępu biologicznego w produkcji roślinnej na podstawie decyzji Ministra Rolnictwa i Rozwoju Wsi nr HOR.hn.802.9.2018, Zadanie 30.

\title{
Mapowanie sprzężeniowe i asocjacyjne owsa zwyczajnego
}

\section{Linkage and association mapping of oat}

\author{
Słowa kluczowe: identyfikacja QTL, mapowanie asocjacyjne, mapowanie sprzężeniowe, mieszańce \\ międzygatunkowe, mieszańce miedzyodmianowe
}

Owies zwyczajny (Avena sativa L.) jest trudnym obiektem badawczym zarówno w klasycznych analizach genetycznych, jak i badaniach molekularnych, z uwagi na skomplikowaną strukturę genomową. Rozwój badań nad owsem w dużej mierze jest limitowany brakiem konsensusowej mapy genetycznej opracowanej w oparciu o ogólnie dostępne markery molekularne. Pierwszym etapem uzyskania tego typu mapy jest wyprowadzenie wielu biparentalnych populacji mapujących doprowadzonych do zaawansowanych linii wsobnych. Szczegółowe mapy konsensusowe umożliwiają typowanie markerów genetycznych sprzężonych z cechami użytkowymi efektywnych na szerokiej puli genetycznej. Inną metodą poszukiwania markerów jest mapowanie asocjacyjne (Brachi i in., 2010). Polega ono na określeniu powiązania markerów genetycznych z cechami morfologicznymi, fizjologicznymi czy biochemicznymi przy zastosowaniu odpowiednich modeli statystycznych (Rex, 2013). Dzięki takiemu podejściu możliwa staje się identyfikacja markerów asocjowanych z QTL cech wielogenowych. 
Do mapowania asocjacyjnego wykorzystuje się niespokrewnione i zróżnicowane pod względem badanych cech odmiany i homozygotyczne linie, które poddaje się szczegółowemu fenotypowaniu i precyzyjnemu genotypowaniu. Do profilowania DNA wykorzystywane są metody skanujące dużą część genomu np. GBS (Huang i in., 2014), DArTseq czy DArT (Elshire i in., 2011; Sansaloni i in., 2011; Kilian i Graner, 2012).

Celem zadania było wyprowadzanie nowych populacji mapujących, kontynuowanie rozmnożeń materiałów przeznaczonych do uzyskania zaawansowanych międzyodmianowych i międzygatunkowych rekombinacyjnych linii wsobnych, identyfikacja QTLi dla wybranych cech w populacji mapującej RIL E56 wyprowadzonej w oparciu o krzyżowanie biparentalne A. fatua $216 \times$ A. sativa 'Sam', identyfikacja sekwencji DARTseq różnicujących osypujące i nieosypujące linie populacji E56, analiza asocjacyjna MTZ linii i odmian $A$. sativa, jak również identyfikacja i testowanie potencjalnych markerów asocjowanych z wysokością roślin.

W ramach projektu wyprowadzono kolejne międzyodmianowe populacje mapujące oraz międzygatunkowe populacje $A$. fatua $\times$ A. sterilis oraz A. sterilis $\times A$. fatua . Otrzymano cztery nowe kombinacje mieszańcowe z genami karłowatości $D w$ : 'Palestine Dwarf' $\times$ 'Bingo' oraz 'Palestine Dwarf' $\times$ 'North Caroline'. Średnia efektywność wszystkich przeprowadzonych krzyżowań wyniosła 9,54\%. Kontynuowano rozmnożenia dotychczas wyprowadzonych międzyodmianowych i międzygatunkowych populacji reprezentujących pokolenia $\mathrm{F}_{1}-\mathrm{F}_{8}$.

Przeprowadzono fenotypowanie międzygatunkowej populacji mapującej RIL $\mathrm{F}_{8}$ E56 A. fatua_216 × A. sativa 'Sam'. Analizowano wysokość, liczbę pędów produkcyjnych i niedogonów, długość wiechy, liczbę kłosków, podatność na osypywanie i obecność ości. Dokonano oceny 10 roślin z każdej linii RIL. W sumie ocenie poddano 150 linii oraz po 30 roślin rodzicielskich. Linie RIL F8 E56 charakteryzowały się wysoką zmiennością pod względem badanych cech, ponadto u mieszańców obserwować można było przekroczenie wartości cech rodzicielskich i tego typu sytuację odnotowano w przypadku wysokości, liczby pędów produkcyjnych, długości wiechy i liczby kłosków $\mathrm{w}$ wiesze. W porównaniu $\mathrm{z}$ formami rodzicielskimi wysokość roślin była bardziej zbliżona do A. fatua, aniżeli do A. sativa. Pomimo dużej liczby kłosków u $A$. sativa, średnia ilość formowanych kłosków w wiesze u mieszańców wyniosła zaledwie 49,2 i była niższa aniżeli średnia wartość tej cechy u $A$. fatua $(52,4)$, przy czym w wiechach poszczególnych linii RIL stwierdzono występowanie od 18,8 do 133,4 kłosków. Określając rozkład wartości cechy w populacji stwierdzono, że tylko wysokość roślin i długość wiechy są dopasowane do rozkładu normalnego. Analiza korelacji cech wykazała, że długość wiechy jest pozytywnie skorelowana z wysokością oraz z liczbą kłosków. Dodatnią korelację stwierdzono również pomiędzy osypywaniem, a liczbą ości.

Fenotypowaniu poddano również rekombinacyjne linie wsobne międzyodmianowej populacji mapującej $\mathrm{F}_{8}$ E101 (Bingo $\times$ STH 9787) oraz formy rodzicielskie tej populacji. Wysokość linii wahała się średnio od 53,6 cm do 129,2 cm, przy czym średnia wysokość dla populacji wyniosła $89,2 \mathrm{~cm}$. Średnia długość wiechy wśród linii RIL $(20,1 \mathrm{~cm})$ była większa, aniżeli stwierdzona u obu form rodzicielskich, ponadto zróżnicowanie wśród linii było bardzo duże i długość wiechy wahała się od zaledwie 12,3 do $27,7 \mathrm{~cm}$. Pomimo 
dużej liczby kłosków formowanych w linii ojcowskiej STH 9787, średnia ilość kłosków $\mathrm{w}$ wiesze u mieszańców wyniosła zaledwie 52,2 , przy czym w wiechach stwierdzono występowanie od 31,0 do 101,3 kłosków. Masa ziarniaków z wiechy u mieszańców była wyższa, aniżeli u obu form rodzicielskich. Określając rozkład wartości cechy w populacji stwierdzono, że tylko w przypadku długości wiechy jest on dopasowany do rozkładu normalnego, podczas gdy pozostałe cechy nie wykazują takiego dopasowania. Analiza korelacji cech wykazała, że wysokość jest pozytywnie skorelowana z długością wiechy i masą ziarniaków. Pozytywną korelację zaobserwowano również pomiędzy liczbą kłosków a liczbą i masą ziarniaków oraz pomiędzy liczbą a masą ziarniaków.

Genotypowaniu metodą DArTseq poddano 120 linii reprezentujących populację mapującą $\mathrm{F}_{2} \mathrm{E} 822$ (A. sterilis 172a $\times$ A. sativa), 150 linii RIL E101 (A. sativa STH9787 $\times$ A. sativa 'Bingo') oraz formy rodzicielskie. Dane uzyskane dla populacji E822 posłużą do weryfikacji markerów dla cech związanych $\mathrm{z}$ udomowieniem owsa uzyskanych w oparciu o analizy genetyczne populacji E52 i E56.

Celem tematu była również identyfikacja QTLi dla wybranych cech w oparciu o populację mapującą $\mathrm{F}_{8}$ E56 (A. fatua $216 \times$ A. sativa 'Sam'). Dla osypywania w populacji E56 zidentyfikowano tylko jeden bardzo silny QTL. Wartość LOD dla tego QTL wynosiła 67,7 , zaś odziedziczalność $63,7 \%$. W przypadku wysokości zidentyfikowano 8 QTLi w obrębie 6 grup sprzężeń.

Z wykorzystaniem danych fenotypowych 370 odmian i linii przeznaczonych do mapowania asocjacyjnego oraz danych genotypowych uzyskanych metodą DArTseq przeprowadzono analizę asocjacyjną dla masy tysiąca ziarniaków z zastosowaniem metod GLM (general linear model - ogólny model liniowy) oraz MLM (mixed linear model wielokrotny model liniowy). Umożliwiała ona identyfikację 2 markerów silicoDArT oraz 4 markerów DArTseq, które asocjowały $\mathrm{z}$ masą tysiąca ziarniaków określoną na podstawie wyników uzyskanych $w$ trzech latach badań (4 powtórzeniach). $\mathrm{W}$ przypadku 48 markerów stwierdzono asocjację z masą tysiąca ziarniaków w trzech spośród czterech niezależnych analiz.

Wykorzystując zidentyfikowane w roku poprzednim sekwencje zasocjowane z wysokością roślin do wybranych $\mathrm{z}$ nich zaprojektowano markery specyficzne. Reakcje PCR przeprowadzono dla odmian i linii o skrajnych fenotypach. Najlepsze dopasowanie segregacji markera asocjowanego z wysokością roślin do fenotypu uzyskano dla dwóch par starterów.

Zidentyfikowane $\mathrm{w}$ roku poprzednim markery SRAP sprzężone $\mathrm{z}$ karłowatością warunkowaną genem $D w 7$ poddano klonowaniu i konwersji do warunków specyficznego PCR. W oparciu o wyniki przeprowadzonych badań do identyfikacji recesywnego allelu genu karłowatości $d w 7$ wytypowano kombinację specyficznych starterów.

W kolejnym etapie prowadzonych analiz zidentyfikowano sekwencje DARTseq różnicujące osypujące i nieosypujące linie populacji E56. Zidentyfikowano 16 takich sekwencji, a analiza BLAST wykazała ich wysokie podobieństwo do znanych genów w innych gatunkach traw, szczególnie biorących udział w kondensacji długołańcuchowych kwasów thuszczowych. 


\section{WNIOSKI}

1. Fenotypowanie międzygatunkowej populacji mapującej RIL $\mathrm{F}_{8}$ E56 A. fatua_216 $\times$ A. sativa 'Sam' oraz międzyodmianowej populacji mapującej RIL F8 E101 (Bingo $\times$ STH 9787) wykazało wysokie zróżnicowanie analizowanych cech.

2. W oparciu o dane fenotypowe i genotypowe dla populacji mapującej F8 E56 A. fatua $216 \times$ A. sativa 'Sam' zidentyfikowano jeden bardzo silny QTL dla osypywania ziarniaków oraz 8 QTLi wysokości roślin.

3. Analiza asocjacyjna umożliwiała identyfikację 2 silnie zasocjowanych z MTZ markerów silicoDArT oraz 4 DArTseq.

4. Opracowano dwa markery specyficzne w oparciu o sekwencje silicoDArT i DArTseq zasocjowane z wysokością roślin.

5. Wytypowano kombinację specyficznych starterów umożliwiającą identyfikację recesywnego allelu genu karłowatości $d w 7$.

6. Zidentyfikowano sekwencje DARTseq różnicujące osypujące i nieosypujące linie populacji E56.

\section{LITERATURA}

Brachi B., Faure N., Horton M., Flahauw E., Vazquez A., Nordborg M., Bergelson J., Cuguen J., Roux F. 2010. Linkage and Association Mapping of Arabidopsis thaliana Flowering Time in Nature. PLoS Genet 6 (5): e1000940.

Elshire R. J., Glaubitz J. C., Sun Q., Poland J. A., Kawamoto K., Buckler E. S., Mitchell S. E. 2011 A Robust, Simple Genotyping-by-Sequencing (GBS) Approach for High Diversity Species. PLoS One 6 (5): e19379.

Huang Y. F., Poland J. A., Wight C. P., Jackson E. W., Tinker N. A. 2014. Using Genotyping By Sequencing (GBS) for genomic discovery in cultivated oat. PLoS ONE 9 (7): e102448. DOI: 10.1371/journal.pone.0102448

Kilian B., Graner A. 2012. NGS technologies for analyzing germplasm diversity in genebanks, Briefinds in functional genomics. Vol.11, No 1: $38-50$.

Rex B. 2013. Genomewide Markers for Controlling Background Variation in Association Mapping. Plant Gen. 10.3835/plantgenome2012.11.0028.

Sansaloni C., Petroli C., Jaccoud D., Carling J., Detering F., Grattapaglia D., Kilian A. 2011. Diversity Array Technology (DArT) and next-generation sequencing combined: genome-wide, high throughput, highly informative genotyping for molecular breeding of Eucalyptus. BMC Proceedings 5 (Suppl. 7): P54. 